\title{
Factors that Influence Accounting Students' Interest in Becoming an Entrepreneur
}

\author{
Pintoro Melin ${ }^{1}$, Wasilah Abdullah ${ }^{1^{*}}$ \\ ${ }^{1}$ Faculty of Economics and Business, Universitas Indonesia, Depok 16424, Indonesia \\ *wasilah.mm@ui.ac.id
}

\begin{abstract}
This study aims to establish accounting students' interest in choosing entrepreneurship as a career option based on the theory of planned behavior. The sample of this research are 2012 and 2013 cohort Accounting students at Universitas Indonesia. The results show that attitudes toward entrepreneurship are positively associated with the interest of accounting students in becoming an entrepreneur. On the other hand, subjective norms have a negative effect on their interest in entrepreneurship. Lastly, accounting and business management does not affect the interest of accounting students in making entrepreneurship a career choice.
\end{abstract}

Keywords: Accounting and Business Management Competencies, Attitude Toward Entrepreneurial, Entrepreneur, Interest, Subjective Norm.

\section{INTRODUCTION}

Along with other countries in ASEAN, by the end of 2015 Indonesia was heading towards an integrated economy, known as the ASEAN Economic Community (EAC). The integrated economy among ASEAN countries will form a single market and production, in which there will be a free flow of goods, services, investments, capital and skilled labor. In anticipation of this, the Government of Indonesia established Law No.7 of 2014 on trade. With the establishment of this law, it was the Government's intention to increase the presence of entrepreneurs in the creation of jobs for the people of Indonesia and to support domestic trade.

In 2015, the number of entrepreneurs in Indonesia was only $1.65 \%{ }^{1}$. The open unemployment rate in Indonesia, according to data from February 2015, was $5.81 \%$ of 128.3 million people ${ }^{2}$. At that time, Indonesia had 3.470 Faculties of Economics. Based on the data, Indonesia should increase the number of entrepreneurs to reduce the unemployment rate.

An entrepreneur is someone who manages, organizes, and takes on business risk. According to research conducted by Farrington, Gray, and Sharp ${ }^{3}$, an entrepreneur is a person who owns and manages a business or enterprise. Being an entrepreneur takes their interest in the field as a career option. Interest in entrepreneurship in research undertaken by Rosmiati, Research on the interest in being an entrepreneur is often based on the theory of planned behavior (TPB).

An entrepreneur requires accounting skills; an inability to understand financial and management accounting will impose themselves as it relates to financial planning and projections that involve investors and bankers in their efforts $^{4}$. The accounting-related capability of an entrepreneur can help to run business activity. In addition to accounting competencies, according to the definition of an entrepreneur, that is, someone who owns and manages a business or enterprise ${ }^{2}$, business management competencies are also necessary.

\section{LITERATURE REVIEW AND HYPOTHESIS DEVELOPMENT}

In this study, the theory used to describe a person's interest in their career choice is that of planned behavior (TPB), which was proposed by Icek Ajzen in 1988. In this theory, three components affect the intention of a person committing the behavior; that is, the attitude towards the behavior (attitude toward the behavior), subjective norms (subjective norms), and perceived behavioral control.

Based on Ajzen ${ }^{5}$, attitudes towards the behavior of the level of evaluation or assessment of a person on a behavior are favorable (favorable) or unfavorable (unfavorable). Subjective norms refer to the perceived social pressure to exercise certain behavior or not. Perceived behavioral control refers to the perceived ease or difficulty in implementing types of behavior. As a main rule, the better the attitude (attitude) and subjective norm with respect to the behavior, and the greater the perceived behavioral control, the stronger the person's intention to display certain behavior in a particular consideration. One's intentions to perform an action will be stronger when it is felt that the action is worthy and desirable ${ }^{6}$.

In TPB, intentions can be defined as attitudes, behavior controls and subjective norms ${ }^{7}$. TPB provides an idea that people take a decision to perform an action based on their intentions and perceptions, which then control one's behavior. In the psychology literature, intentions have been proven to be the best predictors of planned behavior (planned behavior), especially when the behavior is rare, difficult to observe, or involves a time lag that cannot be predicted $^{8}$. According to Krueger ${ }^{9}$ and Martdianty Astuti ${ }^{8}$, entrepreneurship or self-employment (self-employment) 
has been confirmed to be one type of planned behavior.

Lent et al., in Krueger, Reilly, and Carsrud ${ }^{9}$, explain that the selection of one's career reflects the process by which credibility, belief, and intention develop, knowledge, belief and experience. The theory of Planned Behavior can be used in this study to explain the notion that someone's interest in their career choice is based on their intentions and their perceptions of the choices.

\section{Attitudes toward career choice as an entrepreneur (attitudes toward entrepreneurship)}

Attitudes toward behavior in TPB refer to the degree of evaluation or assessment of a person as to whether certain behavior is favorable (favorable) or unfavorable (unfavorable). A person's attitude towards behavior is influenced by their belief in the behavior that will be done. As revealed by Ajzen in Malebana ${ }^{10}$, a person establishes an attitude (attitude) of beliefs they hold about the consequences of different types of behavior. Business and accounting knowledge possessed by students can help in forming a trust will be the consequences of being an entrepreneur. Undergraduate accounting students with business and accounting knowledge can form a trust that is positive or negative for the choice of a career as an entrepreneur. Therefore, this knowledge can form positive or negative attitudes among accounting students towards entrepreneurship as a career option, or not to choose it if they feel their evaluation is negative. Consequently, the attitude towards behavior positively effects the interest in making entrepreneurship a career option.

H1: There is a positive influence on the attitude (attitude towards entrepreneurship) of accounting students in choosing entrepreneurship as a career option.

\section{Subjective norms (subjective norms)}

According to Ajzen ${ }^{5}$, subjective norms refer to the perceived social pressure to exercise certain behavior or not. A subjective norm is formed from the normative belief in the possibility of a person or group reference agreeing to adopt a particular behavior or not. As revealed by Hisrich, Peters, and Shepherd ${ }^{6}$, one of the factors in the success of an entrepreneur is their role model (role model) and support systems. Accounting students around the world have family, friends, seniors, or college networks in the outside world that can provide insight (insight) or support in their career choice. There is a possibility that the role models and support systems of these students take a career choice as an entrepreneur, and this can provide support for the students to choose the same career as an entrepreneur. Therefore, there is a positive effect of the subjective norm on students' interest in accounting to make entrepreneurship a career option.

H2: There is a positive influence of subjective norms on accounting students' interest in choosing entrepreneurship as a career option.

\section{Competence Accounting and Business Management as a proxy of/for? Perceived Behavioral Control}

Accounting and business management competence is required by an entrepreneur. Education is a process of ownership of accounting and business management competencies. The intention of someone to display certain behavior in TPB is also influenced by a third component, namely perceived behavioral control (PBC). According to Ajzen $^{5}$, this component refers to the ease or difficulty felt by a person in performing a behavior. One's control over behavior is influenced by internal and external factors. Internal factors are influenced by the required skills, confidence, and ability to perform behavior. PBC can be measured by three factors, one of which is the controllability of the behavior is under the control of the individual against the willful behavior.

Accounting students with the educational field experienced can be said to have the competence of accounting and business management. Where this competence is required by an entrepreneur, as expressed by Hisrich et al. in Lim, Lee and Cheng ${ }^{11}$, that business management skills which include accounting are among the abilities that fall within the three main areas. The competence of accounting and business owned by management students can provide a positive perception of their ability to become entrepreneurs. The accounting and business management competencies that can be used as a measurement of PBC, since they are an important part of the daily activities of an entrepreneur, have a positive influence on the interest of students in becoming entrepreneurs.

H3: There is a positive influence of accounting and business management competence on accounting students' interest in choosing entrepreneurship as a career option. 


\section{RESEARCH METHOD}

This study aims to determine students' interest in accounting in their choice of entrepreneurship as a career option and the factors that are influenced by the theory of planned behavior. There are three independent variables in the study of attitudes toward the career option of entrepreneurship: subjective norms; accounting and business management competence as a proxy for perceived behavioral control; with the dependent variable being entrepreneurial intention.

In the study, the primary data were collected through a closed question questionnaire ${ }^{12}$. The measurements for each indicator used a Likert scale, with a scale of 1-5. Respondents accessed questionnaires online through Google Forms. The questionnaire in this study was adapted from the studies of Linan and Cohard ${ }^{13}$, Malebana ${ }^{10}$, and Okoro $^{14}$.

The sampling technique was non-probability and purposive sampling. The respondents were active 2012 and 2013 cohort undergraduate Accounting students from the Faculty of Economics and Business, Universitas Indonesia.

Data were analyzed by multiple regression analysis with SPSS 20.0. Multiple regression analysis provides an assessment of the effect between the independent and the dependent variables. Prior to the multiple regression processing of the research data, the validity and reliability were first tested, and the classical assumption test used, consisting of a multicolinearity test, heteroscedasticity test, and normality test (BLUE). Validity and reliability of the data was conducted pre-test and on the final data. Benchmark test the validity according to Malhotra ${ }^{15}$ is a value above $0.5 \mathrm{KMO}$, Bartlett-test significance with a value below 0.05, and factor loadings with values above 0.5. In addition, benchmark test reliability can be measured by Cronbach's Alpha values above 0.6, in accordance with Sekaran and Bougie ${ }^{12}$.

\section{RESULTS AND DISCUSSIONS}

The initial phase of the study conducted a pre-test (pilot test) with 32 respondents as to the validity and reliability of each indicator. The results of the pre-test showed that all indicators were valid, except indicator I (investment) and $\mathrm{T}$ (taxation) in the variables of accounting and business management competence. Both indicators were retained in the study with the assumption that they would be be valid if the number of respondents increased.

For the main test, the total number of respondents was 104. Table 1 shows a summary of the profile of the research respondents:

Table.1. Profile of Respondents

\begin{tabular}{ccc}
\hline Indicator & Amount & $\mathbf{\%}$ \\
\hline \multicolumn{1}{c}{ Gender } & \\
\hline Man & 33 & $32 \%$ \\
\hline Woman & 71 & $68 \%$ \\
\hline \multicolumn{3}{c}{ Cohort } \\
\hline 2012 & 86 & $83 \%$ \\
\hline \multicolumn{2}{c}{ Career Choice } \\
\hline Full Time Entrepreneur & 18 & $17 \%$ \\
\hline Not Full Time Entrepreneur & 11 & $11 \%$ \\
\hline Full Time Private Employee & 33 & $41 \%$ \\
\hline $\begin{array}{c}\text { Full Time Government } \\
\text { Employee }\end{array}$ & 17 \\
\hline The Family Memeber as Entrepreneur \\
\hline Yes & 49 \\
\hline No & 55 \\
\hline
\end{tabular}

The results of the validity and reliability test on the final research data indicate that all indicators are shown to be valid and reliable and meet all BLUE test assumptions. Table 2 displays the multiple regression analysis results. 
Table.2. Multiple Regression Test Results

\begin{tabular}{|c|c|c|}
\hline Dependent Variables & Independent Variables & $\begin{array}{c}\text { Unstandardized } \\
\text { Coefficients B }\end{array}$ \\
\hline \multicolumn{3}{|l|}{$R$ Square: 0.653} \\
\hline \multicolumn{3}{|l|}{ Adjusted $R$ Square: 0.643} \\
\hline \multicolumn{2}{|l|}{$F: 62,813$} & 0,000 \\
\hline \multicolumn{2}{|c|}{ (Constant) } & $2.08 \mathrm{E}-17$ \\
\hline \multirow{3}{*}{$\begin{array}{l}\text { Entrepreneurial } \\
\text { Intention }\end{array}$} & $\begin{array}{l}\text { Attitude Toward } \\
\text { Entrepreneurial }\end{array}$ & $0.830 * * *$ \\
\hline & Subjective Norm & $-0,090 *$ \\
\hline & $\begin{array}{l}\text { Accounting Competencies } \\
\text { and Business Management }\end{array}$ & 0.035 \\
\hline
\end{tabular}

As seen in Table 2, the adjusted R-square is 0.643 . This value is used to assess the goodness of fit of a model. According to Ghozali ${ }^{15}$, this coefficient of determination essentially measures the extent of the ability of the model in explaining the variation of the dependent variable. The adjusted $R$ square value of 0.643 means the study are the independent variables have an impact of $64.3 \%$ on the dependent variable.

In addition to observing the value of the adjusted $R$ square, that of the statistical $F$ tests should also be considered. According to Ghozali ${ }^{15}$, the overall $\mathrm{F}$ test measures the significance of the observed regression and linear estimation and whether Y relates to X1, X2, and X3. The F test compares the F arithmetic (regression result) with the $\mathrm{F}$ table. If the value of the $\mathrm{F}$ arithmetic is greater than the $\mathrm{F}$ table, then $\mathrm{H} 0$ is rejected ${ }^{15}$. The value of the $\mathrm{F}$ table in this study, based on the table F, is equal to 2.70. It can be seen in table 3 that the value of the F arithmetic regression test results is 62.813 , with a significance of 0.000 . Therefore it can be concluded that, together, all the independent variables in the study (attitude toward entrepreneurship, subjective norms, as well as accounting and business management competencies) affect the dependent variable (entrepreneurial intention).

An analysis of the statistical test $t$ was then performed. According to Ghozali ${ }^{15}$, the $t$ test shows the extent of the influence of one independent variable individually in explaining the variation of the dependent variable. An independent variable individually is said to have a positive effect on the dependent variable (or HA is accepted) if the value of $\mathrm{t}$ arithmetic $>$ the t table value. In this study, with a significance level of 95\% (two-tailed) and a degree of freedom of 100, the value of the t table used was 1.984 .

$\mathrm{H} 1$ research is a positive influence on the attitudes towards entrepreneurship on the career option of being an entrepreneur. It can be concluded from this study that the components of the attitude towards the behavior in TPB have a positive influence on entrepreneurial intention. This result is in accordance with research conducted by Malebana $^{10}$ and Hapsari ${ }^{16}$. Based on these results, it can be said that a favorable judgment (favorable) or an unfavorable one (unfavorable) with regard to one's career choice as an entrepreneur will increase or decrease a person's intention to select a career as an entrepreneur.

H2, which posits that there is a positive effect of subjective norms on the interest of accounting students in choosing entrepreneurship as a career option, is rejected. The results show that there is a negative influence of subjective norms on accounting students' interest in choosing entrepreneurship as a career option. The results of this study are in line with research conducted by Krueger et al. ${ }^{9}$, Astuti and Martdianty ${ }^{8}$, and Myers ${ }^{17}$. The negative effect of subjective norms was caused by two factors: (1) the characteristics of the respondents themselves, as revealed by Ajzen in Myers ${ }^{17}$ or (2) the respondents' high locus of control, as expressed by Krueger et al. ${ }^{9}$. The internal locus of control of individuals affects their belief that their behavior is guided by their personal decisions and efforts. This means that students have their own beliefs and career choices. Even if family or peers have chosen entrepreneurship as a career option, students will stay with their own choice. This is evident from the overall average of the entrepreneurial intention variable in the research of only 3.4327 and the interests of students in becoming entrepreneurs in the profile career choice of only $11 \%$.

$\mathrm{H} 3$, which posits that that there is a positive effect of accounting and business management competence as a proportion of the interest of accounting students in their choice of entrepreneurship as a career option, is rejected. The results show that accounting and business management competence has no positive effect on entrepreneurial intention. The results are in line with research conducted by Astuti and Martdianty ${ }^{8}$, and Yousaf, Shamim, Siddiqui, and Raina ${ }^{18}$. The latter found that the level of entrepreneurial abilities and skills of the students did not affect the intention to become an entrepreneur. This is because the acquisition of entrepreneurial abilities and skills is a process that can be increased significantly because of the real situation. Moreover, the cause of accounting and business management competence has no effect on entrepreneurial intention for the curriculum of the accounting 
department FEBUI, who do not prepare graduates to become entrepreneurs. This is evident from the 2012/2013 undergraduate course catalog, in which only eight specializations are suggested in when? taking elective courses.

\section{CONCLUSION}

The conclusion indicates that the factor that positively affects the interest of accounting students in becoming entrepreneurs is their attitude towards the career choice of entrepreneur. The more confidence a student feels in becoming a profitable entrepreneur (favorable), the more interest he/she has in choosing entrepreneurship as a career choice, and vice versa. Subjective norms, however, negatively affect accounting students' interest in becoming entrepreneurs. This suggests that the referral or support of people around the students with regard to their becoming entrepreneurs does not increase their interest in choosing entrepreneurship as a career. Competence in accounting and business management as a proxy of perceived behavioral control does not affect accounting students' interest in becoming entrepreneurs.

Based on the results of this research, several suggestions are made to the Department of Accounting, Faculty of Economics and Business, Universitas Indonesia, and the Government of Indonesia. First, to improve accounting students' interest in becoming entrepreneurs, the Department of Accounting should add an entrepreneurship course as a mandatory course. The second suggestion is related to the importance of investment and taxation knowledge, which has a lower average than other indicators. The Department of Accounting should provide more practical courses or employ experiential learning methods (such as cases, and laboratory work), which will increase the understanding of accounting students of the application of theories. Third, the Government of Indonesia should improve the positive business climate, or other areas that can encourage people to think positively about being entrepreneurs.

There are some limitations in this study which could be improved in subsequent research. First, related to the number of samples and sampling technique, future studies could use more observations so that the results can be more generalized. Second, related to the method of data collection, it is expected that data should be collected by conducting interviews in order to provide more in-depth analysis. Third, related to the use of career choice profiles, it is expected that subsequent research will provide a clearer option of the part-time entrepreneurial option as a career choice.

\section{REFERENCES}

[1] A. Sasongko. Jumlah pengusaha Indonesia hanya 1,65 persen. Republika, (2015) retrieved December $27^{\text {th }} 2015$ from http://www.republika.co.id/berita/nasional/umum/15/03/12/nl3i58-jumlah-pengusaha-indonesia-hanya-165-persen

[2] Badan Pusat Statistik Republik Indonesia. Tingkat Pengangguran Terbuka (TPT) sebesar 5,81 persen, (2015) retrieved December 24 ${ }^{\text {th }}$ 2015, from http://www.bps.go.id/brs/view/id/1139

[3] S. Farrington, B. Gray, and G. Sharp. Perceptions of an entrepreneurial career: do small business owners and university students concur. Management Dynamics, 20(2) (2011) 2-17.

[4] J. W. McKinley and Ellis. Entrepreneurs need accounting too: the case for including financial and managerial accounting in an entrepreneurship curriculum, Cengage, Massachusetts (2014).

[5] I. Ajzen. The theory of planned behavior. Organizational Behavior and Human Decision Process, (1991) 179-211.

[6] P. Hirsch and D. A. Shepperd. Entrepreneurship 10 ${ }^{\text {th }}$ Edition, McGraw-Hill Education, New York.

[7] M. van Gelderen, M. Brand, M. van Praag, W. Bodewes, E. Poutsma, and A. van Gils. Explaining entrepreneurial intentions by means of the theory of planned behavior, Career Development International, (2008) 538-559.

[8] R. D. Astuti, and F. Martdianty. Students entrepreneurial intentions by using theory of planned behavior the case in indonesia, The South East Asian Journal of Management, (2012) 100-112.

[9] N. F. Krueger, M. D. Reilly, and A. L. Carsrud. Competing models of entrepreneurial intentions, Journal of Business Venturing, 15 (2000) 411-432.

[10] J. Malebana. Entrepreneurial intentions of South African rural university students: A test of the theory of planned behaviour, Journal of Economic and Behavioral Studies (2014) 130-143.

[11] Y. M. Lim., T. H. Lee, and B. L. Cheng. Entrepreneurial inclination among business students: a Malaysian study, The South East Asian Journal of Management, (2012) 113-127.

[12] U. Sekaran and Bougie. Research methods for business, John Willey \& Sons Ltd, West Sussex, (2014).

[13] F. Linan and J. C. Cohard. Assessing the stability of graduates' entrepreneurial intention and exploring its predictive capacity, Proquest (2014) 77-98.

[14] J. Okoro. Assessment of accounting competencies possessed by postgraduate university business education students to handle entrepreneurship business challenge in Nigeria, World of Journal Education (2013) 1-10.

[15] I. Ghozali. Aplikasi analisis multivariate dengan program IBM SPSS 23, (2016).

[16] A. A. Hapsari. Analisis pengaruh pendidikan kewirausahaan terhadap intensi berwirausaha mahasiswa ekstensi jurusan manajemen FEUI, Undergradate Thesis, Universitas Indonesia (2013).

[17] D. Myers. The theory of planned behavior as a predictor of entrepreneurial intention in the South African Jewish community, Gordon Institute of Business Science, University of Pretoria, Pretoria, (2014).

[18] U. Yousaf, A. Shamim, H. Siddiqui, and M. Raina. Studying the influence of entrepreneurial attributes,subjective norm and perceived desirability on entrepreneurial intentions. Journal of Entrepreneurship in Emerging Economies, (2014) 23-3 